\title{
Butterfly rash mimicking sunburn erythema
}

Yuji Koike $^{1^{*}}$, Yukako Yokouchi ${ }^{1}$ and Yoshiyuki Chiba ${ }^{2}$

*Correspondence: koikey@tdmc.hosp.go.jp

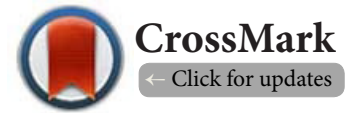

'Department of Pediatrics, Disaster Medical Center, 3256 Midori-cho, Tachikawa, Tokyo, Japan.

${ }^{2}$ Department of Dermatology, Disaster Medical Center, Tokyo, Japan.

\begin{abstract}
The clinical manifestation of childhood systemic lupus erythematosus (SLE) is similar to that of adult SLE; however, the former tends to be more severe and more aggressive than the latter. The prevalence of malar rash in SLE patients was reported to be $50 \%$ to $60 \%$, and the rash may sometimes mimic sunburn erythema, as in our patient; thus, the underlying disease may be misdiagnosed in certain cases.
\end{abstract}

Keywords: Childhood, complement, C-reactive protein, malar rash, systemic lupus erythematosus

\section{Correspondence}

The clinical manifestation of childhood systemic lupus erythematosus (SLE) is similar to that of adult SLE; however, the former tends to be more severe and more aggressive than the latter. The malar rash in SLE patients may sometimes mimic sunburn erythema, as in our patient; thus, the underlying disease may be misdiagnosed in certain cases.

A previously healthy 12 -year-old Japanese girl presented to our outpatient clinic with a rash in early September. She had been well except for easy fatigability and not had an excessive sun exposure. Her physician administered a topical ointment (hydrocortisone butyrate) as treatment for sunburn erythema on the face and an antihistaminergic drug $(10 \mathrm{mg} /$ day of bepotastine besilate ) for urticaria on the trunk and extremities for two weeks. Physical examination revealed a flat, brownish rash on the cheeks and nasal bridge (Figure 1), and an itchy erythematous rash on the trunk and

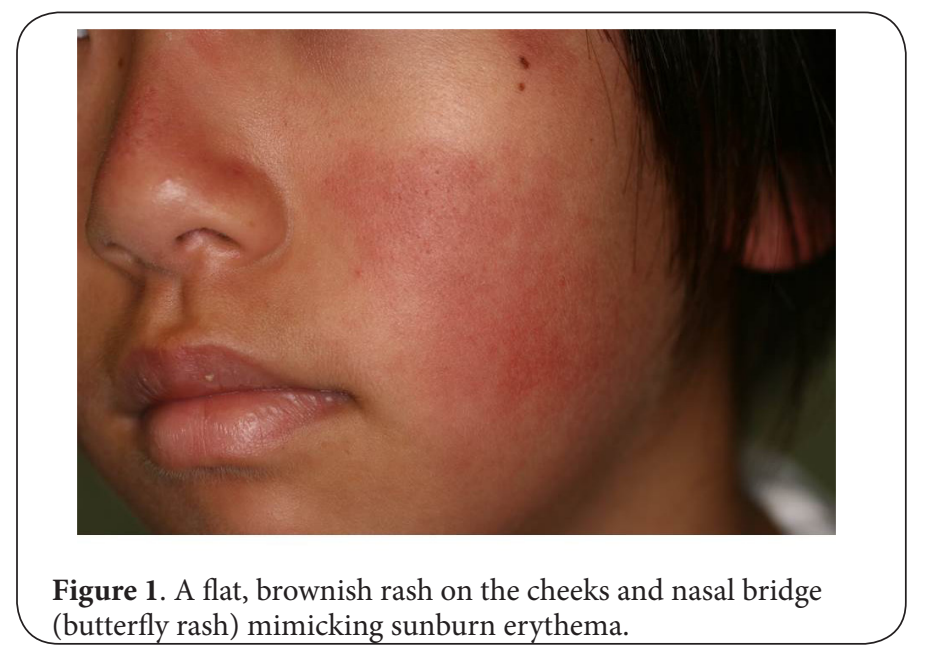

extensor surfaces of the extremities (Figure 2); however, no lymphadenopathy, hepatosplenomegaly, or arthritis was noted. In addition, chest auscultation revealed normal breath sounds. The laboratory findings were as follows: white blood cell count, $3,200 / \mu \mathrm{L}$ with $34 \%$ lymphocytes; hemoglobin level, $11.8 \mathrm{~g} /$ $\mathrm{dL}$; platelet count, $17.2 \times 10^{4} / \mu \mathrm{L}$; aspartate aminotransferase level, $67 \mathrm{IU} / \mathrm{L}$; alanine aminotransferase level, $69 \mathrm{IU} / \mathrm{L}$; lactate dehydrogenase level, $400 \mathrm{IU} / \mathrm{L} ; \mathrm{C}$-reactive protein (CRP) level, $0.02 \mathrm{mg} / \mathrm{dL}$; ferritin level, $117.8 \mathrm{ng} / \mathrm{mL}$; immunoglobulin $\mathrm{G}$ level, $3,120 \mathrm{mg} / \mathrm{dL}$; erythrocyte sedimentation rate (ESR), 120 $\mathrm{mm} / \mathrm{h}$; complement (C) 3 level, $34 \mathrm{mg} / \mathrm{dL}$ (reference range, $77-195 \mathrm{mg} / \mathrm{dL}$ ) ; C4 level, $1 \mathrm{mg} / \mathrm{dL}$ (reference range, 7-40 mg/ $\mathrm{dL}$ ); anti-nuclear antibody titer, $320 \times$ with a speckled pattern; and anti-dsDNA antibody level, $124.5 \mathrm{IU} / \mathrm{mL}$ (reference range,

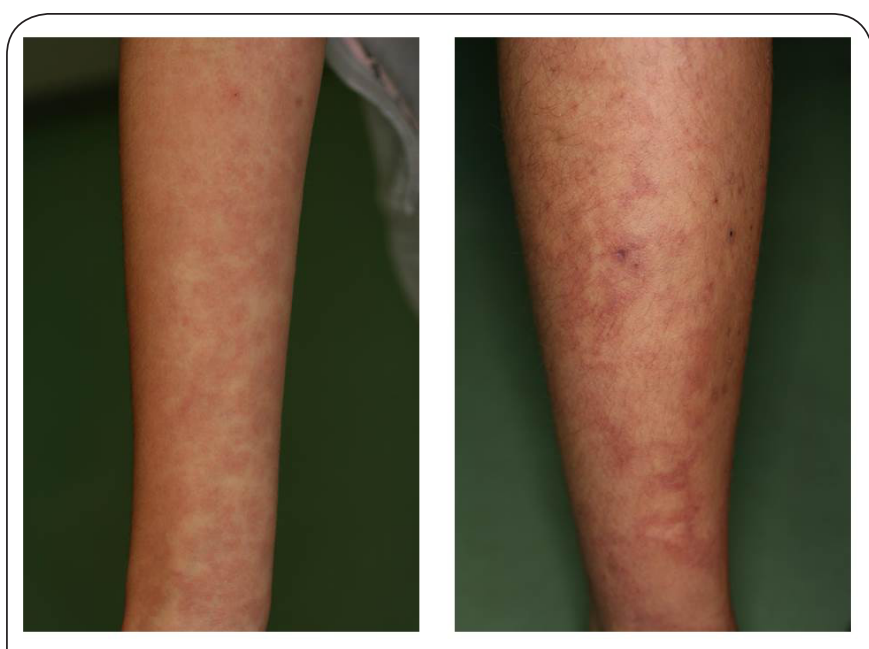

Figure 2. An itchy erythematous rash on the extensor surfaces of the extremities (Left; upper arm, and Right; lower leg).

(C) 2014 Koike et al; licensee Herbert Publications Ltd. This is an Open Access article distributed under the terms of Creative Commons Attribution License (http://creativecommons.org/licenses/by/3.0). This permits unrestricted use, distribution, and reproduction in any medium, provided the original work is properly cited. 
Koike et al. Dermatology Aspects 2014,

$<10 \mathrm{IU} / \mathrm{mL}$ ). On urinalysis, protein $(2+)$ with cellular casts was found. Based on these results, we diagnosed the patient with systemic lupus erythematosus (SLE), because of the presence of 5 of the 11 criteria of the American College of Rheumatology (ACR) 1997 revised classification criteria for SLE [1]. Histopathological examination by a renal biopsy revealed class IV nephritis according to the World Health Organization classification (diffuse proliferative glomerulonephritis affecting $>50 \%$ of glomeruli) [2]. After the diagnosis, she was treated with $40 \mathrm{mg} /$ day of prednisolone and $150 \mathrm{mg} /$ day of mizoribine and the disease had been controlled well.

Childhood-onset SLE is rare, with an estimated incidence rate of $<1$ case per 100,000 children. The clinical manifestation of childhood SLE is similar to that of adult SLE; however, the former tends to be more severe and more aggressive than the latter [3]. The prevalence of malar rash in SLE patients was reported to be $50 \%$ to $60 \%$. In the literature, malar rash is typically described as a slightly raised, bright, erythematous rash on the light-exposed areas of the face (the "butterfly" area). However, the rash may sometimes mimic sunburn erythema [4], as in our patient; thus, the underlying disease may be misdiagnosed in certain cases. In addition to the ACR criteria, low serum complement levels and elevated ESRs with normal CRP levels could be helpful in the diagnosis of SLE [5].

\section{Competing interests}

The authors declare that they have no competing interests.

\section{Authors' contributions}

\begin{tabular}{|l|c|c|c|}
\hline Authors' contributions & YK & YY & YC \\
\hline Research concept and design & $\checkmark$ & $\checkmark$ & $\checkmark$ \\
\hline Collection and/or assembly of data & $\checkmark$ & $\checkmark$ & $\checkmark$ \\
\hline Data analysis and interpretation & $\checkmark$ & $\checkmark$ & $\checkmark$ \\
\hline Writing the article & $\checkmark$ & -- & -- \\
\hline Critical revision of the article & $\checkmark$ & $\checkmark$ & $\checkmark$ \\
\hline Final approval of article & $\checkmark$ & $\checkmark$ & $\checkmark$ \\
\hline
\end{tabular}

Publication history

Editor: Steven Kossard, Skin \& Cancer Foundation, Australia.

Received: 16-Dec-2013 Revised: 22-Dec-2013

Accepted: 27-Dec-2013 Published: 07-Jan-2014

\section{References}

1. Hochberg MC. Updating the American College of Rheumatology revised criteria for the classification of systemic lupus erythematosus. Arthritis Rheum. 1997; 40:1725. | Aritcle | PubMed

2. Pan CG, Avner ED. Glomerulonephritis associated with systemic lupus erythematosus. In: Kliegman RM et al. eds. Nelson textbook of Pediatrics 19th ed. Philadelphia: Elsevier, 2011.

3. Hersh AO, von Scheven E, Yazdany J, Panopalis P, Trupin L, Julian L, Katz $P$, Criswell $L A$ and Yelin E. Differences in long-term disease activity and treatment of adult patients with childhood-and adult-onset systemic lupus erythematosus. Arthritis Rheum. 2009; 61:13-20. | Aritcle | PubMed Abstract | PubMed Full Text

4. Rothfield NF. Systemic lupus erythematosus. In: Fitzpatric TB et al eds.
Dermatology in general medicine 2nd ed. New York: McGraw-Hill, 1979.

5. Ardoin SP, Schanberg LE. Systemic lupus erythematosus. In: Kliegman RM et al eds. Nelson textbook of pediatrics 19th ed. Philadelphia: Elsevier, 2011.

\section{Citation:}

Koike Y, Yokouchi Y and Chiba Y. Butterfly rash mimicking sunburn erythema. Dermatol Aspects. $2014 ; 2: 1$.

http://dx.doi.org/10.7243/2053-5309-2-1 